\title{
Ondersteuningstelsels vir pasiënte met verworwe immuniteitsgebreksindroom
}

\author{
H A Uys, M Cur, Departement Verpleegkunde, RAU \\ SD Roos, D Cur, Senior Lektor, Departement Verpleegkunde, RAU \\ H H M Uys, D Cur, Professor, Departement Verpleegkunde, RAU
}

\section{Opsomming}

Gedurende die navorser se dienstydperk as infeksiebeheerverpleegkundige, was daar noue kontak met pasiënte met Verworwe Immuniteitsgebreksindroom (VIGS). Gedurende hierdie kontak is verskeie behoeftes van die pasiënt met betrekking tot gesondheidsdienste en ondersteuningstelsels geïdentifiseer. Diskriminasie en die toets van pasiënte vir Menslike Immuniteitsgebrekvirus (MIV) teenliggame sonder hulle toestemming, is van die leemtes wat geïdentifiseer is. Die doel van die studie is om die aard en die omvang van die omvattende gesondheidsorgdienslewering vir pasiënte met VIGS te bepaal. Die navorsingsontwerp is 'n kontekstuele, verkennende en beskrywende opname wat in die noordelike helfte van die Gauteng Provinsie uitgevoer is. Kriteria oor die aard en die omvang van omvattende gesondheidsorgdienste te bepaal is met behulp van literatuurstudie opgestel. Data is deur middel van gestruktureerde onderhoude met verpleegkundiges werksaam by die geïdentifiseerde dienste en pasiënte wat van die dienste gebruik maak, ingesamel.

Ter verbetering van dienste is riglyne aan verpleegkundiges voorgehou en aanbevelings, onder andere aspekte van die multi-dissiplinêre spanbenadering, ook gemaak. Vanuit die studie is navorsingtemas geidentifiseer met die doel om beter omvattende gesondheidsorgdienste aan die pasiënt met VIGS te lewer.

\begin{abstract}
During the researcher's time as an infection control professional nurse, close contact was made with patients with Acquired Immunodeficiency Syndrome (AIDS). During this contact period many needs regarding health support were identified. Discrimination, and the testing of patients for Human Immunodeficiency Virus (HIV) antibodies without their permission, were some of the problem areas. The purpose of this study was to determine the nature and extent of comprehensive health care services delivery to patients with AIDS. The research design utilised was a contextual, explorative and descriptive survey which was conducted in the northern half of the Gauteng Province. Criteria to measure the nature and extent of comprehensive health care service delivered to patients with AIDS were based on a literature study. Data was gathered by means of structured interviews with nurses working in identified services and patients that utilised these services.
\end{abstract}

In order to improve the health care services guidelines were given to nursing professionals. Recommendations were also made regarding aspects of the multi-disciplinary team approach. From this study other research topics were identified to enable the health care services to provide better comprehensive health care to the patient with AIDS.

\section{Inleiding}

Ten spyte van al die navorsing wat reeds op dié gebied gedoen is, is daar nog steeds geen voorkomende entstof of geneesmiddel teen VIGS beskikbaar nie. Geneeskundige en verpleegkundige behandeling is slegs simptomaties en ondersteunend van aard. Volgens die Wêreldgesondheidsorganisasie is daar tans wêreldwyd meer as 33,6 miljoen persone met die Menslike Immuniteitsgebrekvirus (MIV) geïnfekteer, waarvan 32,4 miljoen (WGO, 2000:2-2) volwassenes is.

Die verpleegkundige interaksie is gerig op die bevordering, instandhouding en herstel van gesondheid en daarom is dit noodsaaklik dat die verpleegkundige as koordineerder moet optree en doeltreffende pasiëntvoorspraak moet lewer ten einde optimum omvattende gesondheidsorg vir die pasiënt te bekom. 'n Persoon geïnfekteer met die MIV raak liggaamlik, psigies en geestelik so afgetakel dat 'n multi-dissiplinêre spanbenadering en omvattende gesondheidsorg ' $n$ noodsaaklikheid is in sy strewe na heelheid (Sadovosky, 1991:2065). Aangesien die mens op ' $n$ bio-psigososiale wyse, liggaamlik, psigies en geestelik funksioneer, het die persoon met VIGS te doen met die onafwendbaarheid van die dood, en het hy besondere behoeftes en probleme wat aangespreek moet word.

Die onsekerheid wat die persoon met VIGS oor die toekoms ervaar, die ontstaan van skuldgevoelens, die onafwendbaarheid van die dood, asook die moontlike verwerping deur familie, gesin en vriende, is alles faktore wat dit vir die geïnfekteerde persoon byna onmoontlik maak om sonder interaksies en omvattende gesondheidsorgdienste voort te gaan.

Die voorsiening van die fisieke en psigososiale ondersteuning is dus noodsaaklik vir die geïnfekteerde persoon ten einde die 
vraag kan dus gevra word of die huidige omvattende gesondheidsorg werklik vir persone met Verworwe Immuniteitsgebreksindroom voldoende is?

Die doel van hierdie studie was om 'n opname te maak van die aard en omvang van omvattende gesondheidsorgdienste aan persone met Verworwe Immuniteitsgebreksindroom in die noordelike helfte van die Gauteng Provinsie ten einde riglyne aan verpleegkundiges te stel vir die fasilitering van ondersteuningstelsels aan pasiënte met hierdie siektetoestand.

\section{Terminologie}

\section{Mensimmuniteitgebrekvirus positief (serokonversie)}

Dit is die teenwoordigheid van antiliggame teen die mensimmuniteitsgebrekvirus. Die inkubasietydperk van die siekte kan wissel van ses weke tot so lank as 15 jaar. Die siekte word deur ' $n$ retrovirus veroorsaak. Retrovirusse is uniek deurdat hulle die genetiese inligting in selle van RNA na DNA verander. ' $n$ Retrovirus se aksie is dus die teenoorgestelde as die van ander virusse. Omdat die mensimmuniteitsgebrekvirus so maklik muteer, is dit moeilik vir die immuunstelsel om die virus te identifiseer (Van Dyk, 1993:9).

\section{Verworwe immuniteitgebreksindroom}

Dit is 'n siekte wat deur ' $n$ latende stadigwerkende retrovirus veroorsaak word. Dit vernietig die liggaam se immuunstelsel en voorkom dat die persoon homself teen infeksies en sekere kankersoorte kan beskerm. Verworwe immuniteitgebreksindroom is dus ' $n$ sindroom van opportunistiese infeksies, siektes en kankersoorte wat eventueel die geïnfekteerde persoon se dood veroorsaak, deurdat alle tipes bakterieë, fungi en ander virusse die liggaam binne dring en infeksies veroorsaak (Van Dyk, 1993:9).

\section{Sindroom}

Dit is 'n groep simptome en tekens wat gesamentlik kenmerkend is van " $n$ siekte. In verworwe immuniteitgebreksindroom is daar meer as 70 toestande wat, as gevolg van die beskadigde immuunstelsel, kan voorkom (Van Dyk, 1993:5).

\section{Multi-dissiplinêre gesondheidspan}

Hierdie span word beskou as 'n groep professionele gesondheidswerkers wat primêre, sekondêre en tersiêre gesondheidsorg aan die individu, gesin en gemeenskap met 'n gedefiniëerde gesondheidsprobleem, lewer. Hierdie multidissiplinêre span word aangevul deur vrywillige werkers, byvoorbeeld "n lekeberader.

\section{Navorsingsontwerp en-metode}

'n Kontekstuele, verkennende, beskrywende opname-ontwerp was deur die navorser gebruik met 'n literatuurstudie om die ideale omvattende gesondheidsorgdiens vir MIV geïnfekteerde pasiënte te bepaal. Twee groepe respondente is betrek vir gestruktureerde onderhoude. naamlik: Verpleegkundiges wat by die gesondheidsorgdienste werksaam was en pasiënte met
Verworwe Immuniteitsgebreksindroom. Die kriteria vir insluiting van pasiënte by die navorsing behels om:

(a) geinfekteerd te wees met die MIV;

(b) reeds simptome te toon;

(c) met die gesondheidsorgdiens in die noordelike helfte van die Gauteng Provinsie kontak gehad het.

As gevolg van beskikbaarheidsfaktore van pasiënte wat wel aan die kriteria voldoen, is van 'n gerieflikheidsdoelgerigte steekproeftrekkingsmetode soos volg gebruik gemaak:

(a) gerieflik, 'n pasiënt wat tydens die navorser se besoek aan gesondheidsorgdienste teenwoordig was en toestemming tot deelname gegee het;

(b) doelgerig, deurdat al die pasiënte wat aan die studie deelgeneem het aan die kriteria voldoen het.

Hierdie steekproeftrekking is in die noordelike helfte van Gauteng Provinsie gedoen. Twee aparte gestruktureerde onderhoudsgidse is gebruik om die aard en die omvang van die gesondheidsorgdiens te bepaal. Onderhoudsgids nommer een (pasiëntgegewens) wat bestaan het uit die volgende afdelings: biografiese data. patologiese profiel en sosiale beeld, diagnosering, oorsake en bekendmaking van siekte, berading deur gesondheidpersoneel, behandeling, benutting en evaluering van dienste.

Onderhoudsgids nommer twee (fasiliteitgegewens) het die volgende bepaal:

(a) Die beskikbare klinieke vir pasiënte met VIGS

(b) Die verskillende soorte dienste wat deur die klinieke/ hospitale aangebied word.

(c) Of die dienste wat aangebied word, wel vir die pasiënte met VIGS toeganklik is.

(d) Of die dienste aan die spesifieke behoeftes van pasiënte met VIGS voldoen.

(e) Of die verpleegkundige ' $n$ koördineringsfunksie by hierdie gesondheidsorgdienste vir die fasilitering van omvattende gesondheidsorg vervul.

Die individuele onderhoude is gevoer volgens die beginsels van onderhoudvoering soos beskryf deur Uys en Basson, (1991:62-70). Vervolgens is die onderhoude aan die hand van die opnamegids ontleed en beskrywende statistiek in die vorm van frekwensies, persentasies word aangegee en in tabelvorm weergegee.

\section{Betroubaarheid en geldigheid}

Die onderhoudsgidse is gebaseer op 'n literatuurstudie. Sigen inhoudsgeldigheid is verder verseker deur kundige gemeenskapsverpleegkundiges.

\section{Etiese aspekte van studie}

Goedkeuring om die navorsing in openbare hospitale te doen is verkry vanaf die betrokke Hoofdirekteur van Hospitaaldienste, hospitale, klinieke asook ' $n$ plaaslike owerheid. Ingeligte toestemming is van respondente verkry.

'n Loodsstudie is uitgevoer met 'n verpleegkundige van een gesondheidsorgdiens wat in die ondersoekarea val, asook vyf pasiënte wat op daardie stadium die kliniek bygewoon het, toestemming tot die studie verleen het en aan die kriteria 
voldoen het. Die doel van die loodsondersoek was om die geldigheid en betroubaarheid van beide onderhoudsgidse wat in die studie gebruik was te bepaal en om te verseker dat die gesondheidsorgdienste se data-insamelingsinstrumente die gevraagde en korrekte inligting sou inwin.

\section{Konseptuele raamwerk}

Die studie word gegrond op die volgende konseptuele raamwerk.

\section{Patologiese beeld}

Dit is die stadium waarin kliniese tekens en simptome van die siekte verskyn. Aanvanklik kan hy nog selfsorg toepas met die nodige voorligting, soos deur die verpleegkundige gegee, maar in hierdie stadium kan primêre, sekondêre en tersiêre omvattende gesondheidsorg benodig word.

Studies van die natuurlike geskiedenis van infeksies met MIV die toon ' $n$ wye spektrum van siektemanifestasies (Mandell, 1990:1062).

Dit wissel van asimptomatiese infeksies tot lewensbedreigende siektetoestande, soos ernstige immuunonderdrukking, ernstige opportunistiese infeksies en sekere kankersoorte.

Sekere studies het ook 'n duidelike verwantskap tussen die ontwikkeling van lewensbedreigende opportunistiese infeksies en 'n telling van die hoeveelheid CD4+T-limfosiete, (per eenheid bloed, of uitgedruk as 'n persentasie van CD4+T-limfosiete) getoon (CDC, 1992:1).

Studies het ook getoon dat antimikrobiese profilakse en antiretrovirale terapie die effektiefste is tussen sekere vlakke van immuundisfunksie. Daarom word antiretrovirale terapie vir alle persone met ' $\mathrm{C}$ CD4+T-limfosiet-telling van $<500$ per mikroliter bloed aanbeveel. Volgens die "Centers for Disease Control" word profilakse teen Pneumocystis carinii pneumonie, die algemeenste ernstige opportunistiese infeksie, in persone met VIGS, sterk aanbeveel. Dit word ook aanbeveel vir persone met 'n CD4+T-limfosiet-telling van , 200 per mikroliter bloed, sowel as 'n geskiedenis van vorige Pneumocystis carinii pneumonie (CDC, 1992:2; Evian, 1993:202).

Aanvanklike navorsing het daarop gedui dat minder as vyf persent van seropositiewe gevalle gedurende die eerste paar jaar VIGS ontwikkel.

Bahetti in Mandell, et al, (1990:1062) het die eerste 5000 gevalle in San Feransisco bestudeer en bevind dat persone bo die ouderdom van 40 jaar ' $n$ korter oorlewingstydperk het as persone tussen 20 en 39 jaar.

Die langtermynprojeksie van verworwe VIGS ontwikkeling, wys daarop dat die meeste seropositiewe persone ( 78 tot 100 persent) binne 10 tot 15 jaar na infeksie opgedoen is wel VIGS ontwikkel (Lachman, 1991:47).

Kliniese sowel as laboratoriumbevindinge mag help om die siekte-ontwikkeling van 'n seropositiewe persoon te toon. Orale kandidase, wat alreeds 'n opportunistiese infeksie is, is n vroeë kliniese teken van immuunonderdrukking.

Studies deur Corné in Mandell, et al, (1990: 1062) het getoon dat homoseksuele mans met 'n algemene limfadenopatie se risiko om verworwe immuniteitsgebreksindroom te ontwikkel oor 'n tydperk van 18 maande, twaalfvoudig vermeerder in persone met orale kandidase, in vergelyking met persone daarsonder. Harige leukoplakie, wat ook 'n opportunistiese infeksie is en met Epstein Bar-virus geassosieer word, help ook die ontwikkeling van die siekte aan.

Greenspan het in homoseksuele mans met 'n harige leukoplakie in progressiewe styging van opportunistiese infeksies van $48 \%$ in 31 maande getoon (Mandell, et al, 1991:1062).

Gedurende die patogenese stadium kan die pasiënt se toestand wissel van mobiel en selfversorgend tot terminaal.

\section{Klassifikasie tabel}

Die hersiende klassifikasiesisteem van Menslike immuniteitgebrekvirusinfeksie (CDC, 1992:1). Die drie CD4+ Tlimfosiet-indelings is as volg:

- Indeling 1: > $\quad 500$ selle per mikroliter bloed

- Indeling 2: $200-499$ selle per mikroliter bloed

- Indeling 3: <200 selle per mikroliter bloed

Hierdie indelings is volgens die CD4+T-limfosiet-tellings per

\section{Tabel 1: Klassifikasie tabel}

\begin{tabular}{|l|c|c|c|}
\hline CD $4+$ t-sel indelings & $\begin{array}{c}\text { Asimptomatiese } \\
\text { Aku te, (primêre) } \\
\text { MIV of *AAL }\end{array}$ & $\begin{array}{c}\text { Simptomatiese nie } \\
\text { A of C toestande }\end{array}$ & VIGS geassosieerde \\
\hline 1) $>500 / \mathrm{ul}$ & A $~$ & B1 & $\mathrm{C} 1$ \\
\hline 2) $299-499 /$ ul & A2 & B2 & C2 \\
\hline $\begin{array}{l}<\text { 200/ul VIGS } \\
\text { indikasie T-sel } \\
\text { telling }\end{array}$ & A3 & B3 & C3 \\
\hline
\end{tabular}


mikroliterbloed en verleen riglyne vir die kliniese en terapeutiese optredes by die hantering van geïnfekteerde adolessente en volwassenes. Hierdie klassifikasiesisteem laat byvoorbeeld ook ruimte vir die persentasie gebruik van CD4+T-limfosiete. Die laagste akkurate en nie noodwendig die mees onlangse CD4+T-limfosiet-telling moet in die klassifikasie gebruik word (CDC,1992:1).

Volgens hierdie indeling kan die stadium van die siekte bepaal word, wat ook bepaal hoe die geïnfekteerde persoon deur die multi-dissiplinêre gesondheidspan hanteer moet word.

\section{Omgewingsdeterminante van siektes}

Aangepas uit Coetzer, 1983:783

Uit die voorafgaande is dit duidelik dat die persoon se sosiale lewenstyl bydraend tot Verworwe immuniteitsgebreksindroom is.

Die volgende vlakke van gesondheidsorg is van toepassing op die MIV/VIGS pasiënt.

\section{Sosiale beeld}

Figuur 1: Omgewingsdeterminante van siektes

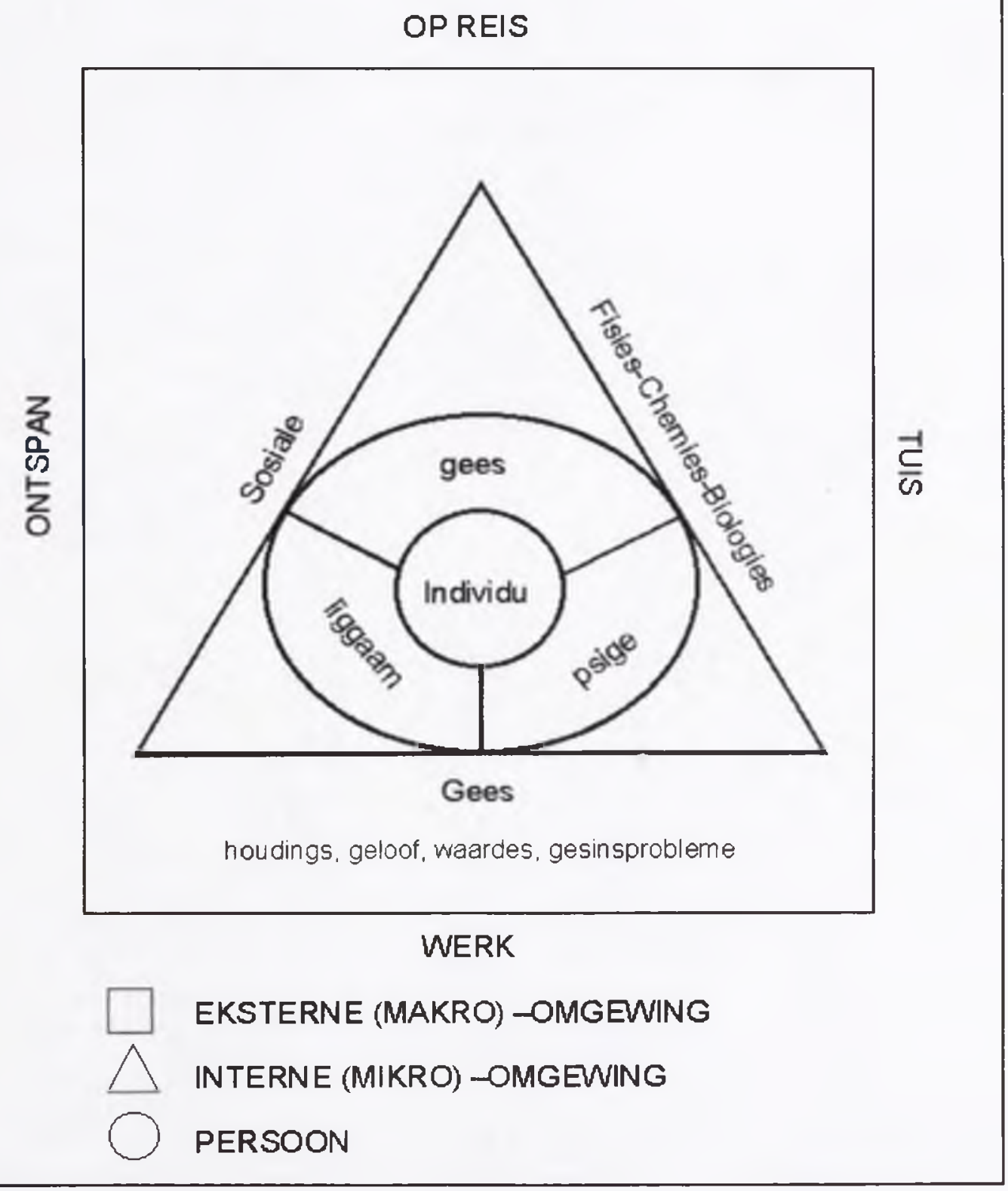




\section{Tabel 2: Vlakke van omvattende gesondheidsorgdienste}

\begin{tabular}{|l|l|l|l|}
\hline $\begin{array}{l}\text { Selfsorg } \\
\text { Tuissorg }\end{array}$ & Primêre gesond heidsorg & $\begin{array}{l}\text { Sekondêre } \\
\text { gesond heidsorg }\end{array}$ & $\begin{array}{l}\text { Tersiêre } \\
\text { gesond heidsorg }\end{array}$ \\
\hline Tuis & $\begin{array}{l}\text { Klinieke, hospitium, } \\
\text { gemeenskaphospitaal }\end{array}$ & $\begin{array}{l}\text { Streekhospitale } \\
\text { met basiese } \\
\text { spesialis dienste }\end{array}$ & $\begin{array}{l}\text { Akademiese hospitale } \\
\text { met alle spesialis } \\
\text { dienste }\end{array}$ \\
\hline Gemeenskap & $\begin{array}{l}\text { Gemeenskapsorgsentrums, } \\
\text { distriksdienste. }\end{array}$ & & \\
\hline
\end{tabular}

Elke vlak van omvattende gesondheidsorg sluit ook die vlakke van interaksie of voorkoming in. (Medunsa, 1993:60; Katoff, 1992:231; Morrison, 1993:317-333).

Interverhoudinge tussen omvattende gesondheidsorgdienste en interaksies (Medunsa, 1993:137)

Omvattende gesondheidsorgdienste sluit ook al vyf vlakke van interaksie in. Om die verhouding tussen die vlakke van interaksie en omvattende gesondheidsorgdienste aan te dui word die twee konsepte in tabelvorm aangedui.

Leavell en Clark (1965:20) beskryf hierdie vlakke van interaksie soos uiteengesit in bogenoemde tabel. Met 'n paradigma van

\section{Resultate}

Enkele resultate wat verkry is deur middel van data wat afkomstig is van die literatuur asook empiriese navorsing word beskryf ten opsigte van die biografiese data, patologiese beeld, sosiale beeld beskrywing van gesondheidsdienste, die aard van omvattende gesondheidsorgdienste, vlakke van omvattende gesondheidsorgdienste en vlakke van interaksie.

\section{Biografiese data}

Meer mans $(\mathrm{N}=31)$ as vrouens $(\mathrm{N}=19)$ was in die ondersoek betrek, met 'n ouderdomsgroep wat wissel tussen 19 en 44 jaar, wat ' $n$ ekonomiese aktiewe en reproduktiewe

\section{Tabel 3: Vlakke van interaksie}

\begin{tabular}{|l|l|}
\hline OMVATTENDE GESONDHEIDSORG & INTERAKSIES \\
\hline Primêre gesondhe idsorg & Vlak 1: Gesondheidsbewusmaking \\
\hline Sekondêre gesondhe idsorg & Vlak 2: Spesifieke beskerming \\
& Vlak 3: Vroeë diagnose en behandeling \\
& Vlak 4: Beperking van ongeskiktheid \\
& Vlak 5: Rehabilitasie \\
\hline Tersiêre gesondheidsorg & \\
\hline
\end{tabular}

mensheelheid volgens Verplegingsteorie vir Mensheelheid, as vertrekpunt, word die vlakke van interaksie soos volg gesien:

- Bevordering van gesondheid:

Vlak 1 en 2

- Instandhouding van gesondheid:

Vlak 3 en 4

- Rehabilitasie: ouderdomsgroep is. Die hevolkingsgroepsamestelling van respondente toon aan dat die meerderheid van die pasiënte swart is. Hierdie bevindinge stem ook ooreen met die nasionale statistiek wat die pasiënt vigssamestelling betref (Epidemiological Comments, Jun. 1999:2-8). Van die respondente was $64 \%(\mathrm{~N}=50)$ ongetroud. 


\section{Patologiese beeld}

Van die pasiënte was $92 \%(\mathrm{~N}=50)$ reeds in hulle tweede en derde stadium van die siekte. Van die deelnemende pasiënte was $96 \%(\mathrm{~N}=50)$ ' $\mathrm{n}$ positiewe status deur middel van seksuele kontak verkry en $28(\mathrm{~N}=50)$ het aangedui dat hulle meer as een seksmaat het. menswaardigheid as baie belangrik aangedui. Volgens die werkende pasiënte $24 \%$ ( $\mathrm{N}=50$ ) was werkgewers bewus daarvan dat hulle siek is. Die reaksie van die werkgewers was van aanvanklik ondersteunend tot ontslag.

\section{Figuur 2: Huwelikstatus van pasient-respondente groep}

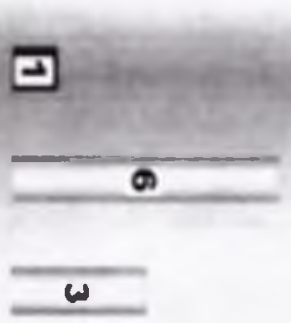

$\overrightarrow{4}$

\section{Tabel 4: Vlakke van Interaksie}

\begin{tabular}{|c|c|c|c|c|}
\hline \begin{tabular}{|} 
Primêre Interaksies \\
Bevordering van gesond heid
\end{tabular} & \multicolumn{2}{|c|}{$\begin{array}{l}\text { Sekondêre Interaksie } \\
\text { Instandhouding van gesond heid }\end{array}$} & $\begin{array}{c}\text { Tersiêre Interaksie } \\
\text { Rehabilitasie }\end{array}$ \\
\hline Vlak 1 & Vlak 2 & Vlak 3 & Vlak 4 & Vlak 5 \\
\hline $\begin{array}{l}\text { Gesond heids- } \\
\text { bewusmaking }\end{array}$ & $\begin{array}{c}\text { Spesifieke } \\
\text { beskerming }\end{array}$ & $\begin{array}{c}\text { Vroeë diagnose } \\
\text { en behandeling }\end{array}$ & $\begin{array}{c}\text { Beperking van } \\
\text { ongeskiktheid }\end{array}$ & Rehabilitasie \\
\hline \multicolumn{2}{|c|}{ pre-patogenese stadium } & patogenese stadium & rehabilitasie \\
\hline
\end{tabular}

\section{Sosiale beeld}

Al die getroude pasiënte ( $\mathrm{N}=50$ ) se eggenote is bewus van die pasiënt se siekte, terwyl slegs $14 \%(\mathrm{~N}=50)$ van die $64 \%$ ongetroud/geskej/saambly-groep van die pasiënt se siekte bewus is. ' $n$ Totaal van 36 (72\%) het ondersteuning en liefde van die gesin/vriende/ouers/ seksmaat en $30 \%(\mathrm{~N}=50)$

\section{Beskrywing van gesondheidsdienste}

In die noordelike helfte van die Gauteng Provinsie is 16 gesondheidsorgdienste doelgerig geïdentifiseer wat alle vlakke van sorg, primêre-, sekondêre en tersiêre gesondheidsorg verteenwoordig. Van die 16 hospitale/klinieke bied twee 'n formele kliniek vir pasiënte met VIGS aan, waarvan een 'n 
akademiese hospitaal en die ander 'n plaaslike owerheidskliniek is. Twaalf van die ander 14 bied ' $n$ VIGS geassosieerde diens aan deur pasiënte vir MIV teenliggame te toets en pasiënte na ander gesondheidsorgdienste te verwys.

\section{Tabel 5: Stadium van siekte waarin die pasient verkeer}

\begin{tabular}{|c|c|c|}
\hline STADIUM & PASIËNTE & $\%$ \\
\hline 1 & 4 & 8 \\
\hline 2 & 27 & 54 \\
\hline 3 & 19 & 38 \\
\hline TOTAAL & 50 & 100 \\
\hline
\end{tabular}

\section{Tabei 6: Aantal seksmaats wat deelnemende pasient die afgelope drie maande} gehad het

\begin{tabular}{|c|c|}
\hline PASIёNTE $(\mathbf{n}=\mathbf{5 0})$ & SEKSMAATS \\
\hline 8 & 0 \\
28 & 1 \\
5 & 2 \\
3 & 3 \\
6 & 4 \\
\hline
\end{tabular}

\section{Tabel 7: Persone wat van die pasient se siekte bewus is}

\begin{tabular}{|l|c|c|}
\hline \multicolumn{1}{|c|}{ PERSONE } & AANTAL & $\%$ \\
\hline Gade & 18 & 36 \\
Geslagsmaat & 7 & 14 \\
Kinders & 1 & 2 \\
Ouers & 12 & 24 \\
Ander Familie & 9 & 18 \\
Vriende & 3 & 6 \\
Ander & 1 & 2 \\
\hline
\end{tabular}

veroorsaak dat die dienste nie vir alle pasiënte bereikbaar is nie. Die gesondheidsorgdienste is wel toeganklik vir alle bevolkings- en ouderdomsgroepe. 


\section{Die aard van omvattende gesondheidsorgdienste}

By die twee beskikbare klinieke is beide verpleegkundiges en maatskaplike werkers verteenwoordig, terwyl 'n geneesheer net by die een diens beskikbaar is. By die ander 12 (d) $38 \%$ bied na-toetsberading aan;

(e) $75 \%$ verwys pasiënte na akademiese hospitale

(f) $36 \%$ doen kliniese ondersoek en behandeling.

\section{Tabel 8: Bydrae ter ondersteuning van die pasient}

\begin{tabular}{|l|c|c|}
\hline \multicolumn{1}{|c|}{ BYDRAE } & GETAL & $\%$ \\
\hline Geen ekstra bydrae nodig nie & 6 & 12 \\
Familie is nie bewus van sy siekte nie & 8 & 16 \\
Kan meer behulpsaam wees & 11 & 22 \\
Meer begrip, liefde en ondersteuning & 36 & 72 \\
Wil meer menswaardig behandel word en nie verwerp & 15 & 30 \\
voel nie & & \\
\hline
\end{tabular}

\section{Tabel 9: Vigs geassosieerde dienste wat deur gesondheidsdienste aangebied word}

\begin{tabular}{|l|c|c|}
\hline \multicolumn{1}{|c|}{ BYDRAE } & GETAL & \% \\
\hline Geen ekstra bydrae nodig nie & 6 & 12 \\
Familie is nie bewus van sy siekte nie & 8 & 16 \\
Kan meer behulpsaam wees & 11 & 22 \\
Meer begrip, liefde en ondersteuning & 36 & 72 \\
Wil meer menswaardig behandel word en nie verwerp & 15 & 30 \\
voel nie & & \\
\hline
\end{tabular}

gesondheidsorgdienste word die multi-dissiplinêre span nie volledig verteenwoordig nie. Die verpleegkundige by die dienste verwys pasiënte hoofsaaklik na die geneesheer, terwyl die dienste van 'n arbeids- en fisioterapeut baie effektief aangewend kan word. Hoewel verpleegkundiges meestal met betrekking tot VIGS opgelei word, wend hulle hulself nie hiervoor aan nie.

\section{Vlakke van omvattende gesondheidsorgdienste}

Al die vlakke van omvattende gesondheidsorgdienste word in die studie verteenwoordig, maar ' $n$ beperkte diens word aan pasiënte met VIGS aangebied. In die studie is die diens as volg geïdentifiseer:

(a) $75 \%$ toets pasiënte by implikasie vir MIV teenliggame;

(b) $68 \%$ bied voorligting oor beperkte onderwerpe aan;

(c) $44 \%$ bied voor-toetsberading aan;
Pasiëntevaluasie van die dienste het getoon dat die gesondheidsorgdienste redelik tot goed is met die volgende leemtes teenoor die pasiënt met VIGS:

(a) $12 \%$ diskrimineer;

(b) $18 \%$ behandel pasiënte nie menswaardig nie;

(c) $90 \%$ toets pasiënte vir MIV teenliggame sonder sy toestemming;

(d) $90 \%$ handhaaf swak geheimhouding;

(e) $40 \%$ bied onvoldoende ondersteuning;

(f) $40 \%$ is moeilik om afsprake by te maak;

(g) $40 \%$ bied onvoldoende medikasie;

(h) $40 \%$ bied onvoldoende voorligting en inligting met betrekking tot VIGS.

\section{Vlakke van interaksie}

Verpleegkundiges bied beperkte voorligting aan en die pasient ervaar die geneesheer as die primêre kontakpersoon en voorligter. Voor-toets, na-toets en opvolgberading word nie 
voldoende aangebied nie. Slegs die gebruik van kondome en seks nadat infeksies opgedoen is, word met die pasiënte bespreek. Beperkte hulpmiddele en metodes word met die aanbied van gesondheidsvoorligting gebruik. Pasiënte ontvang voorligting en inligting uit ander oorde dan gesondheidswerkers. Pasiënte word nog sonder ingeligte toestemming getoets en word ook nie persoonlik van hulle diagnose in kennis gestel nie. Drie-en-sestig persent van die beskikbare dienste bied nie kliniese ondersoeke en behandeling toesien dat pasiënte nie sonder ingeligte toestemming vir MIV teenliggame getoets word nie;

(e) bereid wees om voorligting/opleiding aan ander gesondheidswerkers aan te bied;

(f) bereid wees om die pasiënt te versorg en in 'n verstaanbare taal met hom te kommunikeer;

(g) toe te sien dat al vyf die vlakke van interaksie aan die pasiënt beskikbaar gestel word, en

(h) die pasiënt te verwys wanneer nodig en hom deur die

\section{Tabel 10: Pasiëntervaring van gesondheidsorgdienste}

\begin{tabular}{|l|c|c|}
\hline \multicolumn{1}{|c|}{ GeïDENTIFISE ERDE LEEMTES } & AANT AL & $\%$ \\
\hline Diskriminasie & 6 & 12 \\
Menswaardigheid misken & 9 & 18 \\
Toets sonder toestemming & 45 & 90 \\
Swak geheimhouding & 45 & 90 \\
Onvoldoende ondersteuning & 20 & 40 \\
Afsprake moeilik om te maak & 20 & 40 \\
Onvoldoende medikasie & 20 & 40 \\
Onvoldoende voorligting & 45 & 90 \\
Onvoldoende verwysing & 45 & 90 \\
\hline
\end{tabular}

aan nie.

Pasiënte met VIGS word hoofsaaklik na akademiese hospitale verwys vir verdere hantering. Dit wil voorkom of die gesondheidsorgwerker nie werklik oor riglyne met betrekking tot die hantering sowel as moontlike rehabilitasie van pasiënte met VIGS beskik nie daarom word riglyne aan verpleegkundiges gestel. Psigiese behandeling vorm in $20 \%(\mathrm{~N}=50)$ van gevalle deel van die rehabilitasie komponent.

\section{Riglyne vir verpleegkundiges met die ondersteuning van pasiënte met verworwe immuniteitsgebreksindroom}

Die verpleegkundige behoort:

(a) as koördineerder van die multi-dissiplinêre span te funksioneer om die dienste te fasiliteer;

(b) formele opleiding met betrekking tot VIGS te ontvang en haarself ontwikkel om as berader op te tree;

(c) as berader 'n stabiele, ingeligte persoon met beradingsvaardighede te wees;

(d) voor-toets, na-toets en opvolgberading aan te bied en verskillende fases van sy siekte by te staan en hom ook te help om waardig te sterf.

Verder behoort:

(a) die multi-dissiplinêre span ten opsigte van VIGS opgelei te word. Dit sluit die geneesheer, mediese student, verpleegkundiges, maatskaplike werkers en ander lede van die span in.

(b) Personeel wat by die pasiënt met VIGS betrokke is, behoort emosionele selfondersoek ten opsigte van sy/ haar houding teenoor homoseksualiteit, kultuur- en taalverskille en VIGS te doen.

(c) 'n Handleiding in sakformaat beskikbaar te wees en die kliniese beeld van VIGS, diagnose, behandeling en berading te dek en die handleiding moet op datum gehou word.

(d) Die multi-dissiplinêre span drie tot vier maal per jaar te vergader en selfevaluering te doen.

(e) Formele pasiënt-evaluering van buite die gesondheidsorgdienste (eksterne oudit) op 'n streekproefbasis uitgevoer te word en dit moet die pasiënt se ervaring van die diens te bepaal.

(f) 'n Etiese wye nasionale protokol opgestel te word en 
die wetlike implikasies te dek. Geheimhouding moet ook hoë prioriteit geniet.

(g) Elke gesondheidsorgdiens te besluit tot watter mate die pasiënt behandel moet word en of hy na ' $n$ hospitium verwys moet word.

(h) Die probleem van VIGS, Tuberkulose en seksuele oordraagbare siektes saam aangespreek te word. Skole moet hierby betrek word.

(i) Die kurrikulum van die verpleegkundige ook aangepas te word.

(j) Transkulturele voorligting hoë prioriteit te geniet.

\section{Gevolgtrekkings}

Enkele gevolgtrekkings waartoe in hierdie studie gekom word, is:

(a) Die gesondheidsdienste is wel toeganklik vir VIGS pasiënte van alle bevolkings- en ouderdomsgroepe.

(b) Hoewel verpleegkundiges meesal met betrekking tot VIGS opgelei word, wend hulle hulself nie hiervoor aan nie, wat 'n groot leemte in die dienslewering veroorsaak.

(c) Hoewel pasiënte oor verskeie onderwerpe voorligting ontvang, bied verpleegkundiges werksaam by die dienste oor beperkte onderwerpe voorligting aan.

(d) Pasiënte ontvang nie voldoende voor- en natoets asook opvolgberading nie.

(e) Pasiënte word sonder ingeligte toestemming getoets.

\section{Aanbevelings vir verdere navorsing}

Enkele aspekte wat tydens die navorsing geïdentifiseer is wat verdere navorsing kan verg is die volgende naamlik:
(a) Die verpleegkundige se kennis met betrekking tot
VIGS en haar houding teenoor pasiënte met VIGS.
(b) Die verpleegkundige se agtergrondskennis van rasse, kultuur en taalverskille.
(c) Die ervaring deur die pasiênt van die verpleegkundige as voorligter.
(d) Die rol van die lekeberader/vrywillige werker.

\section{Slot-opmerkings}

Uit die navorsing het dit geblyk dat die pasiënte se persoonlike ondersteuning onvoldoende is en dat optimum gesondheidsorgdienste nie deur gesondheidswerkers aangebied word nie, alhoewel die dienste beskikbaar is. Wat veral 'n probleem blyk te wees is die onvoldoende voorligting wat vir pasiënte aangebied word en dat die multi-dissiplinêre span nie betrokke is nie. Selfondersoek deur gesondheidspanlede ten opsigte van die ondersteuning van VIGS pasiënte tydens hulle langdurige ongesteldheid, is noodsaaklik.

\section{Verwysings}

CENTRES FOR DISEASE CONTROL 1992: Projections of the number of persons diagnosed with Aids and the number of immuno suppressed HIV infected person. United States, 1992, 41 (RR-18). December 1992:1-27.
COETZER, PWW 1983: An Epidemiological approach to health planning in developing regions of South Africa with special reference to Lebowa. Pretoria: Universiteit van Pretoria (MD-proefskrif).

ED(S) 1999: Factors influencing STD and HIV/AIDS clients in South Africa. Epidemiological Comments. 1999, 1(2). 2-8.

EVIAN, C 1993: A practical guide for primary health care personnel in the clinical and supportive care of people with HIV/AIDS. Johannesburg: Jacana.

KATOFF, L 1992: Community based services for people with AIDS. Primary Care: Clinics in Office. 19(1). 18-20.

LACHMAN, SJ 1991: The Emergent Reality of Heterosexual HIV/AIDS. South African Consulting (Pty.) Ltd.

LEAVELL, MD \& CLARK, EG 1965: Preventive Medicine for the doctor in his community. New York: McGrawhill.

MANDELL, GL; DOUGLAS, RG \& BENNET,JE 1990: Principles and Practices of Infectious Diseases. New York: Linvingstone.

MEDUNSA, 1993: Public Health Administration. Department of Community Health, Medunsa (Unpublished).

SADOVSKY, R 1991: Psychosocial issues in symptomatic HIV infection. American Family Physician. 44(6). 21-25.

UYS, HHM \& BASSON, AA 1991: Navorsingsmetodologie in die verpleegkunde. Pretoria: Haum.

VAN DYK, A 1993: From curing to caring nursing and counselling the HIV infected patient. Hospital and Nursing Yearbook of South Africa. 65.

VAN DYK, AC 1992: AIDS counselling in the South African context. In J Uys (Ed.). Psychological counselling in the South African context. Cape Town: Maskew Millar Longman.

WORLD HEALTH ORGINASATION, 2000: Fact sheets on HIV/AIDS. A desktop reference. Geneva: WHO 